\title{
Правовые пределы имущественной ответственности за вред окружающей среде
}

\author{
ХЛУДЕНЕВА Наталья Игоревна, ведущий научный сотрудник отдела экологического зако- \\ нодательства Института законодательства и сравнительного правоведения при Правитель- \\ стве Российской Федерации, кандидат юридических наук \\ 117218, Россия, г. Москва, ул. Большая Черемушкинская, 34 \\ E-mail: khludeneva@mail.ru
}

Правовая природа, содержание, основания и условия применения имущественной ответственности за вред, причиненный окружающей среде, до сих пор не имеют своего однозначного определения ни в доктрине, ни в законодательстве. Не выработан единый подход и в употреблении специальной терминологии, обозначающей ключевые понятия правового института возмещения вреда, причиненного окружающей среде (экологический вред или вред окружающей среде, имущественная или гражданско-правовая ответственность за нарушение законодательства в области охраны окружающей среды и т. д.). Правовой механизм возмещения вреда окружающей среде не лишен и иных концептуальных и юридико-технических дефектов, сдерживающих эфффективность компенсационной и превентивной функций имущественной ответственности за вред окружающей среде, усложняющих текущую практику правореализации в рассматриваемой сфере, создающих условия для возникновения юридических конфоликтов в связи с неоднозначным пониманием субъектами хозяйственной и иной деятельности содержания обязанности по возмещению вреда окружающей среде, отсутствием диффференциации в правовом регулировании применения мер имущественного характера в случае, когда такой вред причинен недобросовестными действиями природопользователей и хозяйственной и иной деятельностью, разрешенной государством, наличием пробелов в порядке определения размера вреда окружающей среде, подлежащего возмещению, вследствие иных неопределенностей в правовом регулировании возмещения вреда окружающей среде. При этом все чаще в последние годы социально-юридическая практика актуализирует вопрос о пределах имущественной ответственности за вред окружающей среде.

Ключевые слова: вред окружающей среде, правовые проблемы возмещения вреда окружающей среде, пределы имущественной ответственности в природоохранной сфрере.

\section{Legal Limits of Property Liability for Environmental Damage}

N. I. KHLUDENEVA, leading research fellow of the Department of environmental legislation of the Institute of Legislation and Comparative Law under the Government of the Russian Federation, candidate of legal sciences

34, Bolshaya Cheremushkinskaya st., Moscow, Russia, 117218

E-mail: khludeneva@mail.ru

The legal nature, content, grounds and conditions for the application of property liability for environmental damage are still not clearly defined either in doctrine or in legislation. No single approach has been developed in the use of special terminology denoting the key concepts of the legal institution of compensation for damage caused to the environment (environmental harm or damage to the environment, property liability for damage to objects of nature or civil liability for damage to the environment, etc.). Such ambiguity complicates the current practice of law enforcement in the sphere under consideration. The practice of compensation for environmental damage shows that the legal mechanism of compensation for such damage is not devoid of conceptual, legal and technical defects that hinder the effectiveness of compensation and preventive functions of property liability 
for damage to the environment. It is also impossible not to pay attention to the presence of litigation in cases of compensation for damage to the environment arising from the ambiguous understanding of nature users of their obligations to compensate for damage to the environment. In the legislation there is no differentiation in the legal regulation of application of measures of property character in the case where such damage was caused by the unfair actions of the users of natural resources and legal economic and other activities which are approved by the state. At the same time, more and more often in recent years, social and legal practice actualizes the issue of the limits of property liability for environmental damage.

Keywords: environmental damage, environmental legislation, legal problems of compensation for environmental damage, the limits of property liability in the environmental field.

DOI: 10.12737/art_2019_3_14

Реализация правовых требований в области охраны окружающей среды, как правило, устанавливающих существенные ограничения хозяйственной и иной деятельности, не может не опираться на силу государственного принуждения. Последняя проявляется в том числе в виде имущественной ответственности за вред окружающей среде, который может быть причинен в результате осуществления такой деятельности.

Специальные условия применения мер имущественного характера к причинителю вреда окружающей среде устанавливает Федеральный закон от 10 января 2002 г. № 7-Ф3 «Об охране окружающей среды» (далее - Закон об охране окружающей среды). Его нормы определяют содержание понятия «вред окружающей среде» (ст. 1), провозглашают возмещение вреда окружающей среде в числе принципов охраны окружающей среды в России (ст. 3), закрепляют обязанность субъектов хозяйственной и иной деятельности, оказывающей негативное воздействие на окружающую среду, по возмещению вреда окружающей среде в полном объеме (ст. 77), устанавливают порядок компенсации вреда окружающей среде, причиненного нарушением законодательства в области охраны окружающей среды (ст. 77, 78).

В соответствии с правовыми установлениями данного Закона юридические и физические лица, причинившие вред окружающей среде в результате ее загрязнения или иного нарушения законодательства в области охраны окружающей среды, обязаны возместить его в полном объеме добровольно либо по решению суда. При этом размер вреда окружающей среде определяется в соответствии с утвержденными в установленном порядке таксами и методиками исчисления размера вреда окружающей среде или исходя из фрактических затрат на восстановление нарушенного состояния окружающей среды.

Примечательно, что об имущественной ответственности Закон об охране окружающей среды упоминает лишь в ст. 75, в которой декларируется о ее установлении наряду с дисциплинарной, административной и уголовной ответственностью за нарушение законодательства в области охраны окружающей среды. При этом законодатель не определил в рассматриваемом Законе содержание данного вида юридической ответственности и не соотнес его с имущественной ответственностью, устанавливаемой Гражданским кодексом РФ. Соответствующие нормы отсутствуют и в самом ГК Р $\Phi^{1}$.

${ }^{1}$ Российский законодатель не всегда избегает прямого указания на возможность применения мер гражданско-правовой ответственности за причинение вреда окружающей среде. Так, Федеральный закон от 5 июня 2012 г. № 50-ФЗ «О регулировании деятельности российских граждан и российских юридических лиц в Антарктике» предусматривает, что оператор (российский гражданин или российское юри- 
Молчание законодателя по такому принципиально важному для правореализации в сорере охраны окружающей среды вопросу порождает немало юридических споров. Так, в правовой науке до сих пор ведется дискурс о допустимости распространения положений гражданского законодательства на отношения, возникающие вследствие причинения вреда окружающей среде.

По аргументированному мнению одних исследователей, вред окружающей среде, во-первых, «причиняется преимущественно вне рамок гражданского правоотношения ${ }^{2}$, во-вторых, он не является разновидностью имущественного вреда, понимаемого в цивилистической науке как нарушение или умаление какого-либо имущественного права или нематериального блага ${ }^{3}$, в-третьих, подход к пониманию вреда окружающей среде с позиций гражданско-правового деликтного обязательства не отражает в полной мере всю специфику такого вреда, правовых последствий его причинения, а также порядка его возмещения ${ }^{4}$.

дическое лицо, организующие и осуществляющие деятельность в Антарктике) несет гражданско-правовую ответственность за вред, причиненный окружающей среде Антарктики (ст. 12).

${ }^{2}$ Бринчук M. М. Возмещение экологического вреда - предмет эколого-правовой ответственности // Правовое регулирование возмещения экологического вреда: науч.-практ. пособие / C. А. Боголюбов, Е. С. Болтанова, М. М. Бринчук [и др.]; отв. ред. Н. В. Кичигин. М., 2017. С. 55.

${ }^{3}$ См.: Мисник Г. А. Понятие экологического вреда // Правовое регулирование возмещения экологического вреда. С. 20-21.

${ }^{4}$ Подробнее см.: Савинъх В. А. Особенности правового режима возмещения вреда окружающей среде природопользователями // Вестник СПбГУ. Сер. 14. 2014. Вып. 3. C. 148-163; Болтанова E. С. Соотношение норм экологического и гражданского законодательства // Правовое регулирование возмещения экологического вреда. С. $66-80$.
Другие ученые отмечают, что «обязательство вследствие причинения вреда природным объектам и комплексам - это гражданско-правовое внедоговорное отношение $»^{5}$, в связи с чем «возмещение вреда, причиненного экологическими правонарушениями, осуществляется в рамках гражданско-правовой ответственности, несмотря на специфику возникающего ущерба, особенности способов его исчисления» ${ }^{6}$.

Несмотря на доктринальные споры, в судебной практике предписания ГК РФ (ст. 15, 1064, 1079 и др.) широко применяются при разрешении споров, возникающих в связи с отказом причинителя вреда окружающей среде возместить его в добровольном порядке. В частности, Верховный Суд РФ в своих ре-

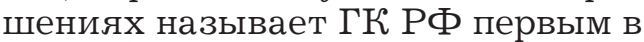
числе нормативных правовых актов, регламентирующих вопросы возмещения вреда, причиненного окружающей среде ${ }^{7}$, а возмещение вреда по утвержденным таксам и методикам признает повышенной имущественной ответственностью, предусмотренной гражданским законода-

${ }^{5}$ Ребиков И. Ю. Возмещение вреда, причиненного природным объектам и комплексам: автореф. дис. ... канд. юрид. наук. Волгоград, 2011. С. 6-8 (цит. по: Болтанова E. C. Указ. соч. С. 74).

${ }^{6}$ Дахненко С. С. Возмещение вреда, причиненного природным объектам и комплексам: авторефр. дис. ... канд. юрид. наук. М., 2001. С. 6 (цит. по: Болтанова Е. С. Указ. соч. C. 74).

${ }^{7}$ См., например, постановления Пленума ВС РФ от 30 ноября 2017 г. № 49 «О некоторых вопросах применения законодательства о возмещении вреда, причиненного окружающей среде», от 18 октября 2012 г. № 21 «О применении судами законодательства об ответственности за нарушения в области охраны окружающей среды и природопользования», от 5 ноября 1998 г. № 14 «О практике применения судами законодательства об ответственности за экологические правонарушения» (утр. силу 17 октября 2012 г.). 
тельством, которая устанавливается с учетом не только материального вреда, но и экологических потерь ${ }^{8}$.

Нормы, регламентирующие вопросы возмещения вреда, причиненного окружающей среде (отдельным природным объектам), содержатся также и в иных федеральных законах - Земельном, Лесном и Водном кодексах Российской Федерации, федеральных законах от 24 апреля 1995 г. № 52-ФЗ «О животном мире» (далее - Закон о животном мире), от 24 июля 2009 г. № $209-\Phi 3$ «Об охоте и о сохранении охотничьих ресурсов и о внесении изменений в отдельные законодательные акты Российской Федерации» (далее - Закон об охоте) и др. При этом в одних законодательных актах почти полностью повторяется правовая модель возмещения вреда окружающей среде, воплощенная в нормах Закона об охране окружающей среды, а в других - предусматриваются некоторые отклонения от нее.

Так, Земельный кодекс РФ обязывает юридических и физических лиц возместить в полном объеме вред, причиненный в результате совершения ими земельных правонарушений, в том числе привести земельные участки в пригодное для использования состояние при их загрязнении, других видах порчи (ст. 76).

В соответствии со ст. 58 Закона об охоте возмещение вреда, причиненного охотничьим ресурсам, осуществляется в добровольном или в судебном порядке на основании утвержденных в соответствии с Законом о животном мире такс и методик исчисления ущерба, причиненного животному миру, а при их отсутствии - исходя из затрат на воспроизводство охотничьих ресурсов.

Несколько иначе к определению порядка возмещения вреда, причи-

${ }^{8}$ См., например, определения ВС РФ от 19 августа 2008 г. № КАС08-430, от 20 октября 2014 г. № 308-ЭС14-3549 по делу № А53$22429 / 2013$. ненного природным объектам, подходит Лесной кодекс РФ, который делит вред, причиненный лесам и находящимся в них природным объектам вследствие нарушения лесного законодательства, на имущественный вред, причиненный лесным участкам и имущественным правам, возникающим при использовании лесов, и вред, причиненный лесам как экологической системе (ст. 100). В первом случае размер возмещения имущественного вреда должен определяться на основе оценки лесов в соответствии с Федеральным законом от 29 июля 1998 г. № 135-ФЗ «Об оценочной деятельности в Российской Федерации», а во втором - в порядке, предусмотренном Законом об охране окружающей среды. Однако на практике вряд ли возможно точно разграничить правовые последствия этих двух разновидностей вреда, причиненного лесам и находящимся в них природным объектам, что, в свою очередь, не позволит избежать случаев возложения по сути двойной имущественной ответственности на причинителя такого вреда.

Некоторые исключения из общего порядка возмещения вреда окружающей среде устанавливает и Закон о животном мире (ст. 56). Он, в частности, провозглашает, что ущерб объектам животного мира и среде их обитания должен быть взыскан с пользователей животным миром, если они не приняли реальных и необходимых мер по предотвращению или уменьшению ущерба на закрепленных за ними территориях, акваториях. Однако определив, по сути, основание для освобождения пользователей объектами животного мира от имущественной ответственности за вред, причиненный таким объектам, законодатель нигде не закрепил понятие или юридически значимые критерии, позволяющие идентифицировать «реальные и необходимые меры по предотвращению или уменьшению ущерба объектам животного мира и среде 
их обитания». В связи с этим предложенный законодателем вариант специальной правовой регламентации возмещения вреда природным объектам нельзя признать удачным.

Накопленная за десятилетия практика возмещения вреда окружающей среде (отдельным природным объектам) показывает, что правовой механизм возмещения вреда окружающей среде не лишен и иных концептуальных и юридико-технических дефектов (как в части определения содержания понятия «вред окружающей среде», так и в части регламентации порядка его возмещения $)^{9}$, с держивающих эфроективность компенсационной и превентивной функций имущественной ответственности за вред окружающей среде.

Также обратим внимание на наличие споров в судебной практике по делам о возмещении вреда окружающей среде, возникающих в связи с неоднозначным пониманием субъектами хозяйственной и иной деятельности содержания своей обязанности по возмещению вреда окружающей среде, отсутствием дифореренциации в правовом регулировании применения мер имущественного характера в случае, когда такой вред причинен недобросовестными действиями природопользователей хозяйственной и иной деятельностью, разрешенной государством (например, деятельностью, документация которой получила

\footnotetext{
${ }^{9}$ Подробнее см.: Жаворонкова Н. Г., Въnханова Г. В. Теоретико-правовые проблемы возмещения вреда, причиненного окружающей среде // Lex Russica. 2018. № 3. С. 52-67; Игнатъева И. А. Актуальные проблемы возмещения вреда окружающей среде (аспекты правового регулирования, судебной практики и реализации государственной политики в области экологического развития) // Экологическое право. 2016. № 4. С. 10-17; Моторин Е. П. Правовые проблемы оценки вреда в сфере природопользования // Общество и право. 2011. № 1. C. $80-83$.
}

положительное заключение государственной экологической экспертизы), вследствие иных неопределенностей в правовом регулировании возмещения вреда окружающей среде $^{10}$. При этом все чаще в последние годы социально-юридическая практика актуализирует проблему определения пределов имущественной ответственности за вред окружающей среде, охватывающую в том числе вопросы применения условно-расчетного метода при определении размера вреда окружающей среде, мер имущественной ответственности за вред окружающей среде, в случае его причинения природопользователем, peaлизующим хозяйственную и иную деятельность, разрешенную государством, обеспечения учета при определении размера вреда окружающей среде затрат на превентивные природоохранные мероприятия, понесенных лицом, причинившим вред.

Основная цель установления мер имущественной ответственности в природоохранной сорере - возмещение в полном объеме причиненного окружающей среде вреда в результате загрязнения и иного негативного воздействия, повлекшего деградацию естественных экологических систем и истощение природных ресурсов.

Однако на практике достижение указанной цели затруднено, так как определить точный размер вреда окружающей среде, как правило, невозможно по ряду следующих причин.

${ }^{10}$ См., например, постановление КС РФ от 2 июня 2015 г. № 12-П, определение КС РФ от 9 февраля 2016 г. № 225-О, решение ВС РФ от 29 марта 2018 г. № АКПИ18-3, апелляционное определение ВС РФ от 3 июля 2018 г. № АПЛ18-231, постановление ФАС Северо-Западного округа от 7 мая 2014 г. № Ф072861/2014 по делу № А 56-42975/2013, постановление Арбитражного суда Западно-Сибирского округа от 28 ноября 2016 г. № Ф044865/2016 по делу № А27-24558/2015. 
Во-первых, природные объекты не имеют заранее определенной цены ${ }^{11}$. В научной литературе подчеркивается, что «окружающая среда - это не обычное имущество, чья утрата может быть компенсирована деньгами. Атмосферный воздух, вода, почвы, экосистемы выполняют важнейшие природные функции и в конечном счете имеют ключевое значение для жизни как таковой. Более того, даже фрлора и фрауна, чьи природные фрунции могут показаться не очевидными, являются ценными в аспекте эстетического удовольствия, которое они приносят, а также в аспекте самого фракта их существования, как форм жизни, требующих уважения и охраны»12.

Во-вторых, неблагоприятные экологические последствия могут проявляться не сразу, а спустя продолжительное время, нося при этом комплексный характер (негативное воздействие может оказываться одновременно на несколько природных объектов $)^{13}$.

В-третьих, исчисление размера компенсации причиненного окружающей среде вреда, осуществляемое в соответствии с методиками и таксами или на основании подсчета

${ }^{11}$ Подробнее см.: Наръишева Н. Г. Возмещение вреда, причиненного нарушением законодательства об охране окружающей природной среды и природных ресурсах: дис. ... канд. юрид. наук. М., 1998; Краснова И. О. Правовое регулирование возмещения экологического вреда // Экологическое право. 2005. № 4. С. $26-34$.

${ }^{12}$ Louise De La Fayette. The Concept of Environmental Damage in International Liability Regimes // Environmental Damage in International and Comparative Law: Problems of Definition and Valuation. Oxford, 2002. Р. 186-187 (цит. по: Савинъц В. А. Указ. соч. С. $148-163)$.

${ }^{13}$ Подробнее см.: Гусев Р. К., Петров В. В. Правовая охрана природы в СССР. М., 1979; Бринчук М. М. Правовая охрана окружающей среды от загрязнения токсичными веществами. M., 1990. стоимости работ по восстановлению нарушенных свойств объектов окружающей среды, не позволяет оценить истинный масштаб такого вреда, так как в подавляющем большинстве случаев определенная сумма денежного возмещения является условной и не соответствует его реальному объему. $\kappa$ тому же не все действующие методики предлагают алгоритм исчисления в стоимостной форме размера вреда природным объектам, не содержащий видимых изъянов.

Например, из подп. «а» п. $5 \mathrm{Me}-$ тодики исчисления размера вреда, причиненного охотничьим ресурсам, утвержденной приказом Министерства природных ресурсов и экологии РФ от 8 декабря 2011 г. № 948, следует, что территория, в границах которой нанесен вред охотничьим ресурсам, может быть отнесена к территории слабого воздействия, характеризующейся снижением численности и годовой продуктивности охотничьих ресурсов от 0 до $24,9 \%$. Однако возникает закономерный вопрос: как территория с нулевым процентом снижения численности и годовой продуктивности охотничьих ресурсов (при условии если все остальные параметры отсутствуют) вообще может быть отнесена к территории, в границах которой нанесен вред охотничьим ресурсам?

Еще один пример. Из подпункта «б» п. 2 названной Методики следует, что действием, влекущим причинение вреда охотничьим ресурсам, является нарушение или уничтожение среды обитания охотничьих ресурсов, если в результате такого нарушения охотничьи ресурсы навсегда (или временно) покинули территорию обитания. При этом не в полной мере ясно, что подразумевается в рассматриваемой Методике под характеристикой «временно покинули» и что делать в случае, когда объекты животного мира «вернулись обратно» в ареал своего обитания, однако причинитель вреда уже успел его возместить. 
Немало проблем возникает и в процессе толкования и применения иных методик, регламентирующих порядок исчисления вреда природным объектам ${ }^{14}$.

Несмотря на то что применение условно-расчетного метода определения размера вреда окружающей среде не позволяет достоверно оценить весь объем затрат на восстановление нарушенного состояния окружающей среды, а исчисленный на основании действующих методик размер вреда окружающей среде может существенно отличаться от его реального размера как в сторону увеличения, так и в сторону уменьшения, в настоящее время именно этому способу определения размера вреда окружающей среде отдается предпочтение в правоприменительной практике, и вряд ли в ближайшее десятилетие

14 Речь в данном случае идет о Методике исчисления размера вреда, причиненного водным объектам вследствие нарушения водного законодательства, утвержденной постановлением Правительства РФ от 4 ноября 2006 г. № 639, действовавшей до 7 января 2019 г., Методике исчисления размера вреда, причиненного лесам, в том числе лесным насаждениям, или не отнесенным к лесным насаждениям деревьям, кустарникам и лианам вследствие нарушения лесного законодательства, утвержденной постановлением Правительства РФ от 8 мая 2007 г. № 273, Методике исчисления размера вреда, причиненного почвам как объекту охраны окружающей среды, утвержденной приказом Минприроды России от 8 июля 2010 г. № 238 (подробнее см.: Омельянюж Г. Г., Михалева Н. В. Правоприменительная практика рассмотрения споров о возмещении ущерба, причиненного экологическими правонарушениями // Имущественные отношения в Российской Федерации. 2012. № 2. С. 90-102; Лунева Е. В. Категория «ассимиляционный потенциал окружающей среды» в судебной практике // Юрист. 2017. № 12. С. 38-42; Воробъев С. Д. Надзор за исполнением природоохранного законодательства // Законность. 2015. № 5. C. $3-7)$. стоит ожидать кардинальных изменений в этом вопросе. В связи с этим по мере развития науки и техники, появления новых знаний о закономерностях фрункционирования экологических систем и влиянии на них хозяйственной и иной деятельности не утрачивает актуальности необходимость совершенствования правил определения количественных параметров негативного воздействия на окружающую среду, установленных в действующих методиках исчисления вреда природным объектам, которые все еще не лишены характеристик произвольности.

Основанием для привлечения лица к имущественной ответственности за вред окружающей среде является противоправное причинение им вреда окружающей среде. Именно правонарушение принято рассматривать и в теории права, и в отраслевых юридических науках в качестве единственного основания любого вида юридической ответственности ${ }^{15}$, в связи с чем правоприменитель обязан установить, является ли тот или иной поступок, деяние правонарушением и содержит ли оно необходимые признаки его юридического состава ${ }^{16}$. В случае причинения вреда окружающей среде по общему правилу необходимо установить противоправность деяния, наличие вреда окружающей среде, вину причинителя вреда, а также причинно-следственную связь между деянием и наступившими неблагоприятными для окружающей среды последствиями.

При этом необходимо учитывать, что законодательство об охране окружающей среды допускает воздействие хозяйственной и иной дея-

${ }^{15}$ См., например: Теория государства и права. Ч. 2 / под ред. М. Н. Марченко. М., 2011; Мелехин A. В. Теория государства и права: учебник. М., 2007; Гражданское право: учебник / под ред. Б. М. Гонгало. Т. 1. 3-е изд. М., 2018.

${ }^{16}$ См.: Теория государства и права. Ч. 2 / под ред. М. Н. Марченко. 
тельности на окружающую среду в пределах установленных нормативов допустимого воздействия (ст. 21 Закона об охране окружающей среды). За превышение указанных нормативов субъекты хозяйственной и иной деятельности в зависимости от причиненного окружающей среде вреда несут ответственность в соответствии с законодательством (п. 3 ст. 21 Закона об охране окружающей среды), т. е. в этом случае предполагается, что в результате их действий причиняется вред окружающей среде (п. 7 постановления Пленума ВС РФ от 30 ноября 2017 г. № 49 «О некоторых вопросах применения законодательства о возмещении вреда, причиненного окружающей среде»).

Таким образом, с учетом текущего нормативного правового регулирования наступление неблагоприятных последствий для окружающей среды (т. е. причинение ей вреда) мозно исключить только при условии соблюдения в процессе осуществления хозяйственной и иной деятельности всех установленных нормативов допустимого воздействия на окружающую среду. Речь в данном случае идет о соблюдении нормативов допустимого воздействия на каждый из компонентов природной среды (леса, объекты животного мира, водные объекты и т. д.), затрагиваемых хозяйственной и иной деятельностью. То есть не может быть признана правомерной деятельность хозяйствующего субъекта, в результате осуществления которой соблюдаются нормативы допустимого воздействия на один из природных объектов, затрагиваемых такой деятельностью, но при этом нарушаются иные нормативы в области охраны окружающей среды (например, осуществление рубки лесных насаждений в объемах, не превышающих нормативы допустимого изъятия древесины (нормативы расчетной лесосеки), на лесных участках, располагающихся на территории общедоступных охотничьих угодий, не исключает возможности причинения вреда охотничьим ресурсам и среде их обитания). Равно как и полученные до начала реализации намечаемой хозяйственной деятельности разрешительные документы (и (или) документация) не освобождают субъекта такой деятельности в дальнейшем от обязанности возместить вред окружающей среде в случае его причинения в результате осуществления такой деятельности.

Вопрос о допустимости возложения обязанности по возмещению вреда окружающей среде, причиненного правомерными (разрешенными государством) действиями, не имеет однозначного ответа. С одной стороны, есть прямое указание на возможность наступления имущественной ответственности за вред, причиненный правомерной деятельностью, в п. 3 ст. 1064 ГК РФ, однако, с другой стороны, Закон об охране окружающей среды вообще не упоминает о том, что возмещение вреда, причиненного правомерными действиями, является мерой, направленной на восстановление нарушенного состояния окружающей среды. Указанный Закон вообще не проводит никакой диффреренциации в правовом регулировании порядка возмещения вреда, причиненного правонарушением или правомерными действиями хозяйствующих субъектов. При этом допускается возможность максимально широкой трактовки понятия «вред окружающей среде», которым охватывается фактически любое изменение качества окружающей среды в результате осуществления как противоправной, так и правомерной антропогенной деятельности ${ }^{17}$.

17 Вред окружающей среде определен в ст. 1 Закона об охране окружающей среды как негативное изменение окружающей среды в результате ее загрязнения, повлекшее за собой деградацию естественных экологических систем и истощение природных ресурсов. Из предложенной законодателем 
В силу ст. 77 Закона об охране окружающей среды юридические и фризические лица, причинившие вред окружающей среде, обязаны возместить его в полном объеме в соответствии с законодательством. При этом обязательному возмещению подлежит также вред окружающей среде, причиненный юридическими лицами и индивидуальными предпринимателями в результате осуществления ими хозяйственной и иной деятельности, в том числе на проект которой имеется положительное заключение государственной экологической экспертизы, включая деятельность по изъятию компонентов природной среды (п. 2 ст. 77 Закона об охране окружающей среды).

Поскольку положительное заключение государственной экспертизы по общему правилу свидетельствует о правомерности осуществляемой хозяйственной деятельности, то одним из распространенных вариантов толкования п. 2 ст. 77 Закона об охране окружающей среды, в том числе в судебной практике, является вывод о том, что действие норм о возмещении вреда окружающей среде должно распространяться и на случаи его причинения в результате осуществления разрешенной государством деятельности хозяйствующих субъектов (в терминологии некоторых исследователей - правомерного экологического вреда ${ }^{18}$ ).

нормы-дефиниции следует, что ключевыми признаками негативного изменения состояния окружающей среды являются деградация естественных экологических систем и истощение природных ресурсов. Однако определения указанных понятий, содержащие их юридически значимые характеристики, данный Закон не содержит, что затрудняет в процессе правоприменения квалификацию последствий изменения состояния окружающей среды в результате реализуемой хозяйственной и иной деятельности как неблагоприятных.

${ }^{18}$ См., например: Кичигин Н. В. Возмещение правомерного вреда // Правовое регули-
Однако нельзя исключить появление на практике иных интерпретаций п. 2 ст. 77 Закона об охране окружающей среды, тем более что в постановлении Пленума ВС РФ от 30 ноября 2017 г. № 49 не нашли отражения официальные разъяснения этого пункта.

Напомним, что в постановлении Пленума ВС РФ от 18 октября 2012 г. № 21 «О применении судами законодательства об ответственности за нарушения в области охраны окружающей среды и природопользования» в редакции, действовавшей до 30 ноября 2017 г., давая оценку вышеобозначенной законодательной норме, Пленум ВС РФ допускал ответственность за вред, причиненный правомерными действиями, рассматривая в качестве таковых и разрешенную государством деятельность (п. 36). С учетом текущего законодательного регулирования, которое в этой части не изменилось, очевидно, что и судебная практика по указанному вопросу должна остаться прежней - обязанность по возмещению вреда окружающей среде, причиненного деятельностью, санкционированной государством, в том числе правомерной, должна возлагаться на лицо, которое эту деятельность осуществляло.

Не имеет также правового значения при определении размера вреда окружающей среде фрактическое осуществление субъектом хозяйственной и иной деятельности превентивных природоохранных мероприятий в целях минимизации негативного воздействия на окружающую среду (отдельные природные объекты).

Так, во-первых, превентивные природоохранные мероприятия направлены на предупреждение причинения вреда окружающей среде, поэтому если, несмотря на их реализацию природопользователем, вред окружающей среде все же был

рование возмещения экологического вреда. C. 152 . 
причинен, то указанные мероприятия были изначально неэфорективны или недобросовестно выполнены. В таком случае даже постановка вопроса о гипотетической возможности учета затрат на проведение таких мероприятий при определении размера вреда окружающей среде видится сомнительной.

Во-вторых, превентивные природоохранные мероприятия проводятся задолго до факта причинения вреда окружающей среде и, как правило, являются обязательным условием осуществления хозяйственной и (или) иной деятельности (см., например, ст. 34 Закона об охране окружающей среды, ст. 44 Закона об охоте, ст. 22 Закона о животном мире, ст. 50 Федерального закона от 20 декабря 2004 г. № 166-ФЗ «О рыболовстве и сохранении водных биологических ресурсов», ст. 42 Водного кодекса РФ).

В-третьих, в соответствии с п. 1 ст. 77 Закона об охране окружающей среды юридические и физические лица, причинившие вред окружающей среде, обязаны возместить его в полном объеме в соответствии с законодательством. В противном случае не будет реализована одна из ключевых идей правового регулирования охраны окружающей среды - принцип «загрязнитель платит», который означает, что лица, оказывающие негативное воздействие на окружающую среду посредством осуществления хозяйственной деятельности, должны нести расходы по возмещению вреда окружающей среде.

При первом приближении такой подход кажется справедливым. Вместе с тем фрактическое уравнивание лиц, активно реализующих природоохранные мероприятия в процессе своей хозяйственной деятельности, и лиц, игнорирующих необходимость проведения таких мероприятий, нельзя признать в полной мере отвечающим задачам охраны окружающей среды, так как в этом случае природопользователь не будет нацелен на активизацию превентивной природоохранной деятельности, направленной на предотвращение и (или) смягчение негативных экологических последствий.

Вышеприведенный анализ показывает: правовое регулирование возмещения вреда окружающей среде не отвечает в полной мере требованию единства и определенности нормативного правового регулирования, что существенно затрудняет процесс правореализации в рассматриваемой сорере. В связи с этим очевидно, что назрела необходимость трансорормации существующей правовой модели возмещения вреда окружающей среде.

Во-первых, требует уточнения норма-дефиниция понятия «вред окружающей среде», сорормулированного в ст. 1 Закона об охране окружающей среды, в которой должны быть четко определены последствия причинения вреда окружающей среде либо критерии, позволяющие отграничить такие последствия от допускаемого государством воздействия на окружающую среду.

Кроме того, необходимо согласовать положения ст. 1 и п. 1 ст. 77 Закона об охране окружающей среды, по-разному определяющих последствия негативного воздействия на окружающую среду, наступление которых квалифицируется как причинение вреда окружающей среде.

Во-вторых, в ст. 2 Закона об охране окружающей среды следует включить положение, устанавливающее соотношение норм гражданского законодательства и законодательства в области охраны окружающей среды в механизме правового регулирования возмещения вреда, причиненного окружающей среде.

В-третьих, необходимо уточнить формулировку п. 2 ст. 77 Закона об охране окружающей среды, в которой допущена серьезная юридико-техническая ошибка, которая 
не только затрудняет понимание ее смысла, но и усложняет восприятие всей юридической конструкции возмещения вреда окружающей среде. Речь в данном случае идет о несогласованности между первой фразой предложения, образующего рассматриваемый пункт, - «вред окружающей среде, причиненный юридическим лицом или индивидуальным предпринимателем», и следующей фразой — «в том числе на проект которой имеется положительное заключение государственной экологической экспертизы, включая деятельность по изъятию компонентов природной среды». О каком проекте идет речь в данном случае и какое он имеет отношение к обязанности по возмещению вреда окружающей среде, можно догадаться, только обратившись к прежней редакции п. 2 ст. 77 Закона об охране окружающей среды, действовавшей до принятия Федерального закона от 21 июля 2014 г. № 219-ФЗ «О внесении изменений в Федеральный закон “Об охране окружающей среды" и отдельные законодательные акты Российской Федерации».

В-четвертых, следует согласовать положения п. 3 ст. 77 и п. 2 ст. 78 За- кона об охране окружающей среды, допускающих разночтение при определении приоритетной формы возмещения вреда окружающей среде.

В-пятых, в рассматриваемом Законе должны быть закреплены особенности (специальный порядок) возмещения вреда окружающей среде, причиненного разрешенной государством деятельностью. Законодателем должен быть учтен факт того, что государство, санкционируя деятельность хозяйствующего субъекта на определенных им же (государством) условиях, включая предоставление конкретной территории или акватории для осуществления такой деятельности, уже на стадии принятия решения фактически допускает возможность наступления неблагоприятных последствий для окружающей среды в границах этой территории или акватории.

В-шестых, в развитие положения п. 2 ст. 78 Закона об охране окружающей среды необходимо ускорить принятие на подзаконном нормативном правовом уровне порядка учета затрат по устранению вреда окружающей среде при определении его размера.

\section{Библиографический список}

Louise De La Fayette. The Concept of Environmental Damage in International Liability Regimes // Environmental Damage in International and Comparative Law: Problems of Definition and Valuation. Oxford, 2002.

Болтанова Е. С. Соотношение норм экологического и гражданского законодательства // Правовое регулирование возмещения экологического вреда // Правовое регулирование возмещения экологического вреда: науч.-практ. пособие / С. А. Боголюбов, Е. С. Болтанова, M. М. Бринчук [и др.]; отв. ред. Н. В. Кичигин. М., 2017.

Бринчук M. M. Возмещение экологического вреда — предмет эколого-правовой ответственности // Правовое регулирование возмещения экологического вреда: науч.-практ. пособие / С. А. Боголюбов, Е. С. Болтанова, М. М. Бринчук [и др.]; отв. ред. Н. В. Кичигин. М., 2017.

Бринчук M. M. Правовая охрана окружающей среды от загрязнения токсичными веществами. М., 1990.

Воробьев С. Д. Надзор за исполнением природоохранного законодательства // Законность. 2015. № 5 .

Гражданское право: учебник / под ред. Б. М. Гонгало. Т. 1. 3-е изд. М., 2018.

Гусев Р. К., Петров В. В. Правовая охрана природы в СССР. М., 1979.

Дахненко С. С. Возмещение вреда, причиненного природным объектам и комплексам: автореф. дис. ... канд. юрид. наук. М., 2001.

Жаворонкова Н. Г., Выпханова Г. В. Теоретико-правовые проблемы возмещения вреда, причиненного окружающей среде // Lex Russica. 2018. № 3. 
Игнатьева И. А. Актуальные проблемы возмещения вреда окружающей среде (аспекты правового регулирования, судебной практики и реализации государственной политики в области экологического развития) // Экологическое право. 2016. № 4.

Кичигин Н. В. Возмещение правомерного вреда // Правовое регулирование возмещения экологического вреда // Правовое регулирование возмещения экологического вреда: науч.практ. пособие / С. А. Боголюбов, Е. С. Болтанова, М. М. Бринчук [и др.]; отв. ред. Н. В. Кичигин. М., 2017.

Краснова И. О. Правовое регулирование возмещения экологического вреда // Экологическое право. 2005. № 4.

Лунева Е. В. Категория «ассимиляционный потенциал окружающей среды» в судебной практике // Юрист. 2017. № 12.

Мелехин А. В. Теория государства и права: учебник. М., 2007.

Мисник Г. А. Понятие экологического вреда // Правовое регулирование возмещения экологического вреда // Правовое регулирование возмещения экологического вреда: науч.практ. пособие / С. А. Боголюбов, Е. С. Болтанова, М. М. Бринчук [и др.]; отв. ред. Н. В. Кичигин. М., 2017.

Моторин Е. П. Правовые проблемы оценки вреда в сфере природопользования // Общество и право. 2011. № 1.

Нарышева Н. Г. Возмещение вреда, причиненного нарушением законодательства об охране окружающей природной среды и природных ресурсах: дис. ... канд. юрид. наук. М., 1998.

Омельянюк Г. Г., Михалева Н. В. Правоприменительная практика рассмотрения споров о возмещении ущерба, причиненного экологическими правонарушениями // Имущественные отношения в Российской Федерации. 2012. № 2.

Ребиков И. Ю. Возмещение вреда, причиненного природным объектам и комплексам: автореф. дис. ... канд. юрид. наук. Волгоград, 2011.

Савиных В. А. Особенности правового режима возмещения вреда окружающей среде природопользователями // Вестник СПбГУ. Сер. 14. 2014. Вып. 3.

Теория государства и права. Ч. 2 / под ред. М. Н. Марченко. М., 2011.

\section{References}

Boltanova Ye. S. Sootnoshenie norm ekologicheskogo i grazhdanskogo zakonodatelstva: poisk balansa [Correlation of Norms of Environmental and Civil Legislation: a Search for the Balance]. Pravovoe regulirovanie vozmeshcheniya ekologicheskogo vreda. S. A. Bogolyubov, Ye. S. Boltanova, M. M. Brinchuk [et al.]. Ed. by N. V. Kichigin. Moscow, 2017. Pp. 66—80.

Brinchuk M. M. Pravovaya okhrana okruzhayushchey sredy ot zagryazneniya toksichnymi veshchestvami [Legal Protection of Environment from Pollution by Toxic Substances]. Moscow, 1990. 214 p.

Brinchuk M. M. Vozmeshchenie ekologicheskogo vreda - predmet ekologo-pravovoy otvetstvennosti [Reparation of Environmental Damage - Subject of Environmental Liability]. Pravovoe regulirovanie vozmeshcheniya ekologicheskogo vreda. S. A. Bogolyubov, Ye. S. Boltanova, M. M. Brinchuk (et al.). Ed. by N. V. Kichigin. Moscow, 2017. Pp. 50—66.

Dakhnenko S. S. Vozmeshchenie vreda, prichinennogo prirodnym obektam i kompleksam: grazhdansko-pravovoy aspekt [Reparation of Damage Caused to Natural Objects and Complexes: Civil Law Aspect]. Cand. diss. thesis. Moscow, 2001. 237 p.

Grazhdanskoe pravo [Civil Law]. Ed. by B. M. Gongalo. Vol. 1. $3^{\text {rd }}$ ed. Moscow, 2018. 528 p.

Gusev R. K., Petrov V. V. Pravovaya okhrana prirody v SSSR [Legal Protection of Environment in the USSR]. Moscow, 1979. 176 p.

Ignateva I. A. Aktualnye problemy vozmeshcheniya vreda okruzhayushchey srede (aspekty pravovogo regulirovaniya, sudebnoy praktiki i realizatsii gosudarstvennoy politiki v oblasti ekologicheskogo razvitiya) [Topical problems of indemnification of environmental damage (aspects of legal regulation, judicial practice and realization of state policy in the field of ecological development)]. Ekologicheskoe pravo, 2016, no. 4, pp. 10-17.

Kichigin N. V. Vozmeshchenie pravomernogo vreda [Reparation of Legal Environmental Damage]. Pravovoe regulirovanie vozmeshcheniya ekologicheskogo vreda. S. A. Bogolyubov, Ye. S. Boltanova, M. M. Brinchuk [et al.]. Ed. by N. V. Kichigin. Moscow, 2017. Pp. 151-164. 
Krasnova I. O. Pravovoe regulirovanie vozmeshcheniya ekologicheskogo vreda [Legal Regulation of Reparation of Environmental Damage]. Ekologicheskoe pravo, 2005, no. 4, pp. 26 33.

Louise De La Fayette. The Concept of Environmental Damage in International Liability Regimes. Environmental Damage in International and Comparative Law: Problems of Definition and Valuation. Oxford, 2002. 349 p.

Luneva Ye. V. Kategoriya "assimilyatsionnyy potentsial okruzhayushchey sredy" v sudebnoy praktike ["Assimilation Potential of Environment" Category in Court Practice]. Yurist, 2017, no. 12 , pp. $38-42$.

Melekhin A. V. Teoriya gosudarstva i prava [Theory of State and Law]. Moscow, 2007. 640 p.

Misnik G. A. Ponyatie ekologicheskogo vreda [Definition of Environmental Damage]. Pravovoe regulirovanie vozmeshcheniya ekologicheskogo vreda. S. A. Bogolyubov, Ye. S. Boltanova, M. M. Brinchuk (et al.). Ed. by N. V. Kichigin. Moscow, 2017. Pp. 20-38.

Motorin Ye. P. Pravovye problemy otsenki vreda v sfere prirodopolzovaniya [Legal Problems of Harm Estimation in the Sphere of Nature Management]. Obshchestvo $i$ pravo, 2011, no. 1, pp. $80-83$.

Narysheva N. G. Vozmeshchenie vreda, prichinennogo narusheniem zakonodatelstva ob okhrane okruzhayushchey prirodnoy sredy i prirodnykh resursakh [Reparation of Damage Caused Violation of Legislation on the Protection of the Environment and Natural Resources]. Cand. diss. Moscow, 1998. 182 p.

Omelyanyuk G. G., Mikhaleva N. V. Pravoprimenitelnaya praktika rassmotreniya sporov o vozmeshchenii ushcherba, prichinennogo ekologicheskimi pravonarusheniyami [Practice Review of Disputes on Compensation for Damage Caused by Environmental Violations]. Imushchestvennye otnosheniya $v$ Rossiyskoy Federatsii, 2012, no. 2, pp. 90-102.

Rebikov I. Yu. Vozmeshchenie vreda, prichinennogo prirodnym obektam i kompleksam [Reparation of Damage Caused to Natural Objects and Complexes]. Cand. diss. thesis. Volgograd, 2011. $30 \mathrm{p}$.

Savinykh V. A. Osobennosti pravovogo rezhima vozmeshcheniya vreda okruzhayushchey srede prirodopolzovatelyami [Peculiarities of the Legal Framework for Compensation of Environmental Damages by Natural Resource Users]. Vestnik SPbGU, seriya 14, 2014, iss. 3, pp. $148-163$.

Teoriya gosudarstva i prava [Theory of State and Law]. Part 2. Ed. by M. N. Marchenko. Moscow, 2011. $336 \mathrm{p}$.

Vorobev S. D. Nadzor za ispolneniem prirodookhrannogo zakonodatelstva [Supervision over Implementation of Environmental Legislation]. Zakonnost, 2015, no. 5, pp. 3-7.

Zhavoronkova N. G., Vypkhanova G. V. Teoretiko-pravovye problemy vozmeshcheniya vreda, prichinennogo okruzhayushchey srede [Theoretical and Legal Problems of Compensation for Harm Caused to the Environment]. Lex Russica, 2018, no. 3, pp. 52-67. 